\section{Prevalence of Nosocomial Infections in Adult Intensive Care Units at a Kosova Teaching Hospital}

To the Editor-Nosocomial infections constitute an important public health challenge worldwide. They result in high morbidity and mortality, prolonged hospital stays, greater use of antibiotics, and increased costs. ${ }^{1,2}$ The burden of this problem is highest in intensive care units (ICUs). Nosocomial infection rates in ICUs, even in highly developed countries, are $25 \%$ $35 \%$, with mortality exceeding $25 \%$, whereas in developing countries, two-thirds of patients admitted to intensive care suffer at least 1 nosocomial infection. ${ }^{3}$ We report on a survey of the prevalence of nosocomial infection in adult ICUs at the University Clinical Centre of Kosova (UCCK).

The health care sector in Kosova has scarce human and material resources. It receives only €35 per capita per year. Infection control in Kosova is taking the first steps towards establishing national policies in prevention and control of nosocomial infections. In the past, within the UCCK and 5 county hospitals, hospital infection control committees existed solely on paper. The awareness of nosocomial infection increased during the last few years, and, in May 2006, the Ministry of Health established the National Committee for Prevention and Control of Nosocomial Infections as the executive body to combat this challenge. The first study of the prevalence of nosocomial infections in targeted high-risk areas, undertaken in 2003 at UCCK, showed an overall prevalence of $17.4 \%$ ( 29 infections in 167 patients). ${ }^{4}$

The UCCK is the only tertiary care center in Kosova. It has 2,400 beds and serves 2.1 million inhabitants. Our study used a point prevalence methodology and was performed on September 15, 2006, in the 3 ICUs at UCCK. Patient data were obtained from medical records and by physical examination. Data on the following types of infection were recorded: nosocomial pneumonia, nosocomial urinary tract infection, surgical site infection, and nosocomial bloodstream infection. The US Centers for Disease Control and Prevention criteria were used to define nosocomial infections. ${ }^{5}$ Specimens of endotracheal aspirate, sputum, and urine, as well as nasal, throat, axillar, and perineal swab specimens, were obtained from all patients. Diagnostic bacteriologic testing was done using standard procedures in the Department of Microbiology at the National Institute for Public Health of Kosova.

Of 28 patients surveyed, 11 had a total of 18 nosocomial infections. Of these 18 nosocomial infections, which all occurred in the central ICU, ventilator associated pneumonia accounted for $8(44.4 \%)$, bloodstream infections for 5 $(27.8 \%)$, urinary tract infections for $4(22.2 \%)$, and surgical site infection for $1(5.6 \%)$.

The overall prevalence rate was $64.3 \%$. The mean age of the patients was 42.1 years (SD, 15.3 years). The median length of stay before the survey was 17.3 days (range, 2-112 days). No infections were detected in the pulmonological and neurological ICUs. In the central ICU, $68.7 \%$ of patients had nosocomial infections, with a predominance of ventilator associated pneumonia ( $72.7 \%$ of infections).

Laboratory testing yielded isolates for $26 \%$ of patients. Gram-negative bacilli represented $63.6 \%$ of all isolates, with a predominance of Acinetobacter species (27.2\%) and Pseudomonas aeruginosa ( $18.2 \%)$. Of the 28 surveyed patients, 17 $(60.7 \%)$ were receiving antimicrobial treatment at the time of the survey.

The prevalence of nosocomial infections in Kosova is higher than in other European countries, where estimates range from $20 \%$ to $35 \% .{ }^{6}$ The high prevalence in Kosova can be attributed to many factors: a lack of financial support, inadequate numbers of trained personnel working in infection control, understaffed hospital units, and insufficient equipment and supplies. These results emphasize the need for infection prevention interventions in ICUs.

\section{ACKNOWLEDGMENTS}

Potential conflicts of interest. All authors report no conflicts of interest relevant to this study.

Gazmend Spahija, MD; Lul Raka, MD; Gjyle Mulliqi, MD, PhD; Nexhmije Spahija, MD; Zana Bukoshi, MD; Faton Hoxha, MD, PhD; Avdyl Krasniqi, MD, PhD

From the Intensive Care Unit (G.S., N.S., Z.B.) and the Department of Surgery (F.H., A.K.), University Clinical Centre of Kosova, and the National Institute for Public Health of Kosova (L.R., G.M.), and the School of Medicine, Prishtina University (L.R., G.M., A.K.), Prishtina, Kosova.

Address reprint requests to Lul Raka, MD, Emin Duraku No. 166, 71000 Kaçanik, Kosova, UNMIK (lulraka@hotmail.com).

Infect Control Hosp Epidemiol 2008; 29:475-475

(C) 2008 by The Society for Healthcare Epidemiology of America. All rights reserved. $0899-823 \mathrm{X} / 2008 / 2905-0023 \$ 15.00$. DOI: $10.1086 / 533480$

\section{REFERENCES}

1. Wenzel RP, ed. Prevention and Control of Nosocomial Infections. 4th ed. Philadelphia, PA: Lippincott, Williams \& Wilkins; 2003:14-33.

2. Lynch P, Jackson M, Preston GA, Soule BM. Infection Prevention With Limited Resources. Chicago: ETNA Communications; 1997.

3. Eggimann P, Pittet D. Infection control in the ICU. Chest 2001; 120:20592093.

4. Raka L, Zoutman D, Mulliqi GJ, et al. Prevalence of nosocomial infections in the high risk units at the University Clinical Center of Kosova. Infect Control Hosp Epidemiol 2006; 27:421-423.

5. Garner JS, Jarvis WR, Emori TG, Horan TC, Hughes JM. CDC definitions for nosocomial infections. Am I Infect Control 1988; 16:128-140.

6. Vincent JL, Bihari DJ, Suter PM, et al. The prevalence of nosocomial infection in intensive care units in Europe. JAMA 1995; 274:639-644. 